\title{
Dissipation Pattern of Chlorpyriphos, Cypermethrin, Ethion, Profenophos and Triazophos in Curry Leaf
}

\author{
Shashi Vemuri*, Kavitha K, Swarupa Rani S
}

AINP on Pesticide Residues PJTSAU, Hyderabad, Telangana state, India

*Corresponding author: Shashi Vemuri, AINP on Pesticide Residues PJTSAU, Hyderabad, Telangana state, India, E-mail: sash_3156@yahoo.co.in / kaviangrau@gmail.com

\begin{abstract}
Studies were conducted for determining the residues of Chlorpyriphos, Cypermethrin, Ethion, Profenophos and Triazophos in Curry leaf which were detected the most in market samples by conducting field experiments after spraying twice during 2015 - 2016 and analyzed using QuEChERS method on LC-MS/MS. As there are no MRLs for curry leaves, it should be considered as most important to fix MRLs to ensure food safety and consumer health and to create awareness among the farmers about the application dose, method of application and Pre-harvest Intervals. The mismanagement or non-availability of proper information about the pesticide application can lead to contamination of pesticide residues in curry leaf. The findings of this study provided important data on dissipation of pesticide residues in curry leaf and hence, it is essential to conduct dissipation studies in other curry leaf growing agro climatic regions, which may serve as basis for future policy about the standards and quality control of pesticides.
\end{abstract}

Received Date: September 17, 2016 Accepted Date: November 14, 2016 Published Date: November 24, 2016

Citation: Vemuri, S., et al. Dissipation Pattern of Chlorpyriphos, Cypermethrin, Ethion, Profenophos and Triazophos in Curry Leaf. (2016) Int J Food Nutr Sci 3(2): 372-377.

DOI: $10.15436 / 2377-0619.16 .1127$

Keywords: Curry Leaf; Quechers method; Chlorpyriphos; Cypermethrin; LC-MS/MS

\section{Introduction}

Murraya koenigii L. (curry leaf) belonging to family Rutaceae is a leafy spice characterizing authentic Asian-Indian cuisine and it is used in small quantities for its distinct aroma as well as for preservation purposes. Curry leaf oil an volatile oil, produced from the plant has uses in the soap industry ${ }^{[1]}$. Recent studies have shown that carbazole alkaloids have several biological activities such as anti carcinogenic effects in dimethyl hydrazine $(\mathrm{DMH})$ treated rats ${ }^{[2]}$, anti platelet activity and vaso relaxing effects ${ }^{[3]}$. Chevalier (1996) ${ }^{[4]}$ also reported that curry leaf has medicinal value as traditionally used in Eastern Asia. Interest in greater use of curry leaf has been stimulated since its high antioxidant potency was reported and this antioxidant activity is attributed due to mahanimbine, murrayanol and mahanine from M. koenigii ${ }^{[5,6]}$. Chowdhury et al. $(2001)^{[7]}$ reported that these alkaloids have antimicrobial activity against gram positive and negative bacteria, and fungi. Lee et al. $(2002)^{[8]}$ 
noted that enrichment of phenolic compounds within the plant extract is correlated with their enhanced antioxidant activity. It is reported to have antioxidant, anti-diabetic, anti-carcinogenic, antidysenteric stimulant, hypoglycemic and anti microbial activities $^{[2]}$. Biologically active carbazole alkaloids are reported to have anti microbial properties ${ }^{[9]}$. Curry leaves have been reported to contain tocopherol, b-carotene, lutein and alkaloids ${ }^{[2]}$. But it is observed that curry leaves have received red alert message from the European Union, who are the major importers, where the pesticide residue limits were found much beyond the permissible levels. This created a panic among the mass as curry leaves constitute a major spice exported from India.

Uncontrolled use of pesticides and non-adoption of safe waiting periods has led to pesticide accumulation in curry leaf crop. The residues being persistent in nature infiltrate crops, contaminate water, pollute complete food chain and enter our body through diet. Pesticide exposure may produce biochemical alterations in the body long before adverse clinical health effects are manifested ${ }^{[10]}$.

\section{Materials and Methods}

\section{Market study}

For the dissipation of pesticide residues of commonly detected pesticides a field experiment was conducted utilizing Chlorpyriphos 20\% EC @ 300 g.a.i/ha (1500 ml/ha),Cypermethrin 10 \% EC@50 g.a.i/ha (550 ml/ha),Ethion 50\% EC @ 500 g.a.i/ha (1250 ml/ha), Profenophos 50\% EC @ 500 g.a.i/ ha (1250 ml/ha) and Triazophos 40\% EC@ @ 500 g.a.i/ha (1250 $\mathrm{ml} / \mathrm{ha}$ ) twice, first at vegetative stage and 10 days later. Zero day samples were collected for estimation of deposits of pesticide within 2 hours of last spray, and the samples of curry leaf were collected at $0,1,3,5,7,10,15,20,25,30$ and 35 days after last spray for residue estimation. Each sample was processed and analyzed for determination of pesticides. Samples were analyzed within 24 hrs.

\section{Sample extraction procedure}

Curry leaf samples were analyzed for pesticide residues following the AOAC Official Method 2007.01 (QuEChERS) after validation of the method in the laboratory. The samples were collected randomly from 5 locations of the market in polythene bags. Each sample was homogenized separately with Robot Coupe Blixer and homogenized $15 \pm 0.1 \mathrm{~g}$ sample was taken in $50 \mathrm{ml}$ centrifuge tube and $30 \pm 0.1 \mathrm{ml}$ acetonitrile was added to sample tube. The sample was homogenized at $14000-15000$ rpm for $2-3$ min using Heidolph Silent Crusher. $3 \pm 0.1$ g sodium chloride was added to sample, mixed thoroughly by shaking gently followed by centrifugation for $3 \mathrm{~min}$ at $2500-3000 \mathrm{rpm}$ to separate the organic layer. The top organic layer of about 16 $\mathrm{ml}$ was taken into the $50 \mathrm{ml}$ centrifuge tube and added with $9 \pm$ $0.1 \mathrm{~g}$ anhydrous sodium sulphate to remove the moisture content. $8 \mathrm{ml}$ of extract was taken into $15 \mathrm{ml}$ tube, containing $0.4 \pm$ 0.01 g PSA sorbent (for dispersive solid phase d-SPE cleanup), $1.2 \pm 0.01 \mathrm{~g}$ anhydrous magnesium sulphate and $0.05 \mathrm{~g}$ of GCB (Graphatised Carbon Black). The sample tube was vortexed for $30 \mathrm{sec}$ then followed by centrifugation for $5 \mathrm{~min}$ at $2500-3000$ $\mathrm{rpm}$. The extract of about $1 \mathrm{ml}(0.5 \mathrm{~g}$ sample $)$ was taken for analysis on LCMS/MS under standard operational conditions (Table-1).
- $500 \mathrm{~g}$ of curry leaf was collected randomly from each plot in polythene bags.

- The samples were homogenized with Robot Coupe Blixer.

- $15 \pm 0.1 \mathrm{~g}$ of homogenized sample was taken in $50 \mathrm{ml}$ centrifuge tube and $30 \pm 0.1 \mathrm{ml}$ acetonitrile was added.

- The sample was homogenized at $14000-15000 \mathrm{rpm}$ for $2-3$ min using Heidolph Silent Crusher.

- The samples were then added with $3 \pm 0.1 \mathrm{~g}$ sodium chloride, mixed by shaking gently, followed by centrifugation for $3 \mathrm{~min}$ at $2500-3000 \mathrm{rpm}$ to separate the organic layer.

- The top organic layer of about $16 \mathrm{ml}$ was taken into the $50 \mathrm{ml}$ centrifuge tube and added with $9 \pm 0.1 \mathrm{~g}$ anhydrous sodium sulphate to remove the moisture content.

- $8 \mathrm{ml}$ of extract was taken into $15 \mathrm{ml}$ tube, containing $0.4 \pm$ $0.01 \mathrm{~g}$ PSA sorbent (for dispersive solid phase d-SPE cleanup), $1.2 \pm 0.01 \mathrm{~g}$ anhydrous magnesium sulphate and $0.03 \mathrm{~g}$ of GCB (Graphatize Carbon Black) to remove pigments.

- The sample tube was vortexed for $30 \mathrm{sec}$ then followed by centrifugation for $5 \mathrm{~min}$ at $2500-3000 \mathrm{rpm}$.

- The extract of about one $\mathrm{ml}$ was transferred into a vial for LCMS/MS analysis under standard operational conditions.

\section{LCMS/MS Instrument Parameters}

\begin{tabular}{|c|c|c|}
\hline LC-MS/MS & \multicolumn{2}{|c|}{ SHIMADZU LC-MS/MS - 8040.} \\
\hline Detector & \multicolumn{2}{|l|}{ Mass Spectrophotometer } \\
\hline Column & \multicolumn{2}{|c|}{ Kinetex, $2.6 \mu, \mathrm{C} 18$ Column, $100 \times 3.0$. } \\
\hline $\begin{array}{l}\text { Column oven } \\
\text { temperature }\end{array}$ & \multicolumn{2}{|l|}{$40^{\circ} \mathrm{C}$} \\
\hline Retention time & \multicolumn{2}{|c|}{$\begin{array}{l}\text { Profenophos }-16.15 \mathrm{~min} \text {, Triazophos-13.21 } \\
\text { min, Chlorpyrifos }-16.75 \mathrm{~min} \text {, Cypermethrin } \\
-17.4 \mathrm{~min} \text {, Ethion-16.6 min }\end{array}$} \\
\hline Nebulizing gas & \multicolumn{2}{|c|}{ Nitrogen } \\
\hline Nebulizing gas flow & \multicolumn{2}{|l|}{2.0 litres $/ \mathrm{min}$} \\
\hline Pump mode/ flow & \multicolumn{2}{|l|}{ Gradient $/ 0.4 \mathrm{ml} / \mathrm{min}$} \\
\hline LC Solvents & \multicolumn{2}{|c|}{$\begin{array}{l}\text { A: Ammonium Formate in Water }(10 \mathrm{Mm}) \\
\text { B: Ammonium Formate in Methanol }(10 \mathrm{Mm})\end{array}$} \\
\hline \multirow[t]{10}{*}{ LC programme } & Time A Conc. & B Conc. \\
\hline & 0.01 & 35 \\
\hline & 2.00 & 35 \\
\hline & 7.00 & 60 \\
\hline & 9.00 & 60 \\
\hline & 14.00 & 95 \\
\hline & 17.00 & 85 \\
\hline & 19.00 & 70 \\
\hline & 21.00 & 35 \\
\hline & 24.00 & 35 \\
\hline $\begin{array}{l}\text { Total Time } \\
\text { Programme }\end{array}$ & \multicolumn{2}{|l|}{$24 \mathrm{~min}$} \\
\hline
\end{tabular}


Chlorpyriphos, Cypermethrin, Ethion, Profenophos and Triazophos in Curry Leaf

Table 1: Recovery of Profenophos at various fortification levels in Curry leaf.

\begin{tabular}{|l|c|c|c|c|c|c|}
\hline \multirow{2}{*}{ pesticides } & \multicolumn{2}{|c|}{$\mathbf{0 . 0 5} \mathbf{~ m g} / \mathbf{k g}$} & \multicolumn{2}{c|}{$\mathbf{0 . 2 5} \mathbf{~ m g} / \mathbf{k g}$} & \multicolumn{2}{c|}{$\mathbf{0 . 5 ~ m g / k g}$} \\
\cline { 2 - 7 } & $\begin{array}{l}\text { Calculated Level } \\
(\mathbf{m g} / \mathbf{k g}) \text { Average }\end{array}$ & \% Recovery & $\begin{array}{l}\text { Calculated Level } \\
\text { (mg/kg) Average }\end{array}$ & \% Recovery & $\begin{array}{l}\text { Calculated Level } \\
\text { (mg//kg) Average }\end{array}$ & \% Recovery \\
\hline Profenophos & 0.053 & 106.66 & 0.207 & 83.06 & 0.488 & 98.06 \\
\hline Triazophos & 0.043 & 85.33 & 0.210 & 84.00 & 0.488 & 97.60 \\
\hline Chlorpyriphos & 0.047 & 94.66 & 0.261 & 104.53 & 0.578 & 115.60 \\
\hline Cypermethrin & 0.058 & 115.33 & 0.244 & 97.60 & 0.574 & 114.86 \\
\hline Ethion & 0.05 & 101.33 & 0.205 & 82.00 & 0.506 & 101.13 \\
\hline
\end{tabular}

Linearity graph of Chlorpyriphos, Cypermethrin, Ethion, Profenophos and Triazophos is represented in Figure1.
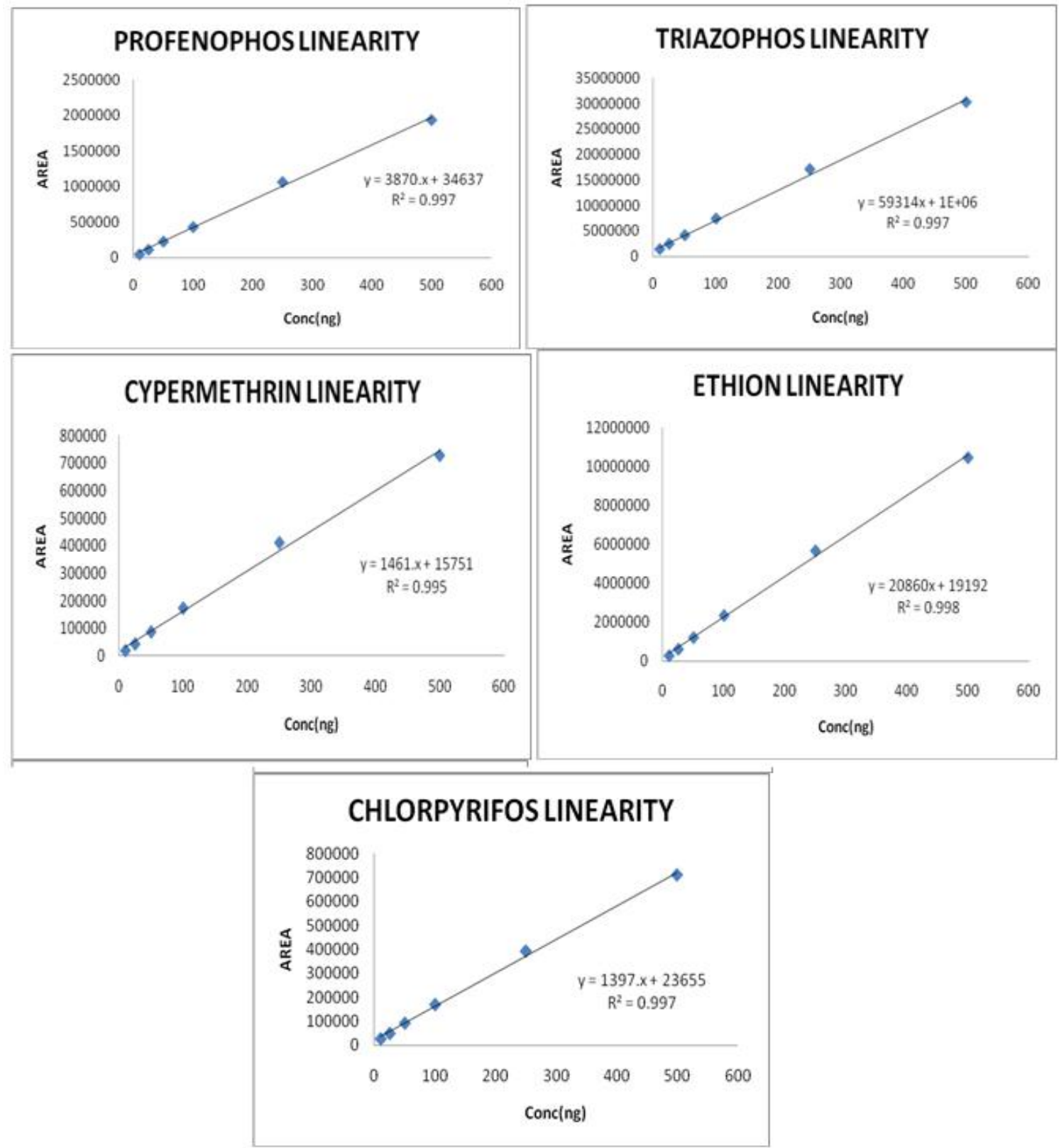

Figure 1: Linearity graph of Chlorpyriphos, cypermethrin, ethion, profenophos and triazophos.

Fortification and recovery studies

- The untreated curry leaf samples were fortified at $0.05,0.25$, and $0.50 \mathrm{mg} / \mathrm{kg}$ levels adding required quantity of Chlorpyriphos, Cypermethrin, Ethion, Profenophos and Triazophos standards.

- All the fortified levels were replicated thrice.

- Recoveries of Chlorpyriphos, Cypermethrin, Ethion, Profenophos and Triazophos at three fortification levels are presented in Table 2, Figure 2. 
Chlorpyriphos, Cypermethrin, Ethion, Profenophos and Triazophos in Curry Leaf

Table 2: Residues and dissipation of in curry leaf.

\begin{tabular}{|c|c|c|c|c|c|c|c|c|c|c|}
\hline \multirow{2}{*}{$\begin{array}{l}\text { Days after } \\
\text { Treatment }\end{array}$} & \multicolumn{2}{|c|}{ Profenophos } & \multicolumn{2}{|c|}{ Triazophos } & \multicolumn{2}{|c|}{ Chlorpyrifos } & \multicolumn{2}{|c|}{ Cypermethrin } & \multicolumn{2}{|c|}{ Ethion } \\
\hline & $\begin{array}{l}\text { Mean } \\
(\mathrm{mg} / \mathrm{kg})\end{array}$ & $\begin{array}{l}\% \\
\text { Dissipation }\end{array}$ & $\begin{array}{l}\text { Mean } \\
(\mathrm{mg} / \mathrm{kg})\end{array}$ & $\begin{array}{l}\text { \% } \\
\text { Dissipation }\end{array}$ & $\begin{array}{l}\text { Mean } \\
(\mathrm{mg} / \mathrm{kg})\end{array}$ & $\begin{array}{l}\% \\
\text { Dissipation }\end{array}$ & $\begin{array}{l}\text { Mean } \\
(\mathrm{mg} / \mathrm{kg})\end{array}$ & $\begin{array}{l}\% \\
\text { Dissipation }\end{array}$ & $\begin{array}{l}\text { Mean } \\
(\mathrm{mg} / \mathrm{kg})\end{array}$ & $\begin{array}{l}\% \\
\text { Dissipation }\end{array}$ \\
\hline 0 & 55.14 & - & 21.65 & - & 18.86 & & 39.06 & & 31.12 & \\
\hline 1 & 49.73 & 9.81 & 21.03 & 2.86 & 8.79 & 53.39 & 26.88 & 31.18 & 29.96 & 3.72 \\
\hline 3 & 35.66 & 35.33 & 19.69 & 9.05 & 2.11 & 88.81 & 17.70 & 54.69 & 26.53 & 14.75 \\
\hline 5 & 30.68 & 44.36 & 17.31 & 20.05 & 1.52 & 91.94 & 15.69 & 59.83 & 25.69 & 17.45 \\
\hline 7 & 25.86 & 53.09 & 8.95 & 58.66 & 1.17 & 93.80 & 12.99 & 66.74 & 21.10 & 32.2 \\
\hline 10 & 23.81 & 56.81 & 6.95 & 67.90 & 1.06 & 94.38 & 11.14 & 71.48 & 20.54 & 34.00 \\
\hline 15 & 19.16 & 65.24 & 4.70 & 78.29 & 0.89 & 95.28 & 7.44 & 80.95 & 17.23 & 44.63 \\
\hline 20 & 3.22 & 94.16 & 0.07 & 99.68 & 0.08 & 99.58 & BDL & $\mathrm{BDL}$ & 16.43 & 47.2 \\
\hline 25 & BDL & BDL & BDL & BDL & BDL & BDL & & & 1.66 & 94.67 \\
\hline 30 & & & & & & & & & 0.80 & 97.43 \\
\hline 35 & & & & & & & & & BDL & \\
\hline
\end{tabular}

$\mathrm{BDL}=$ Below determination level $(<0.05 \mathrm{mg} / \mathrm{kg})$
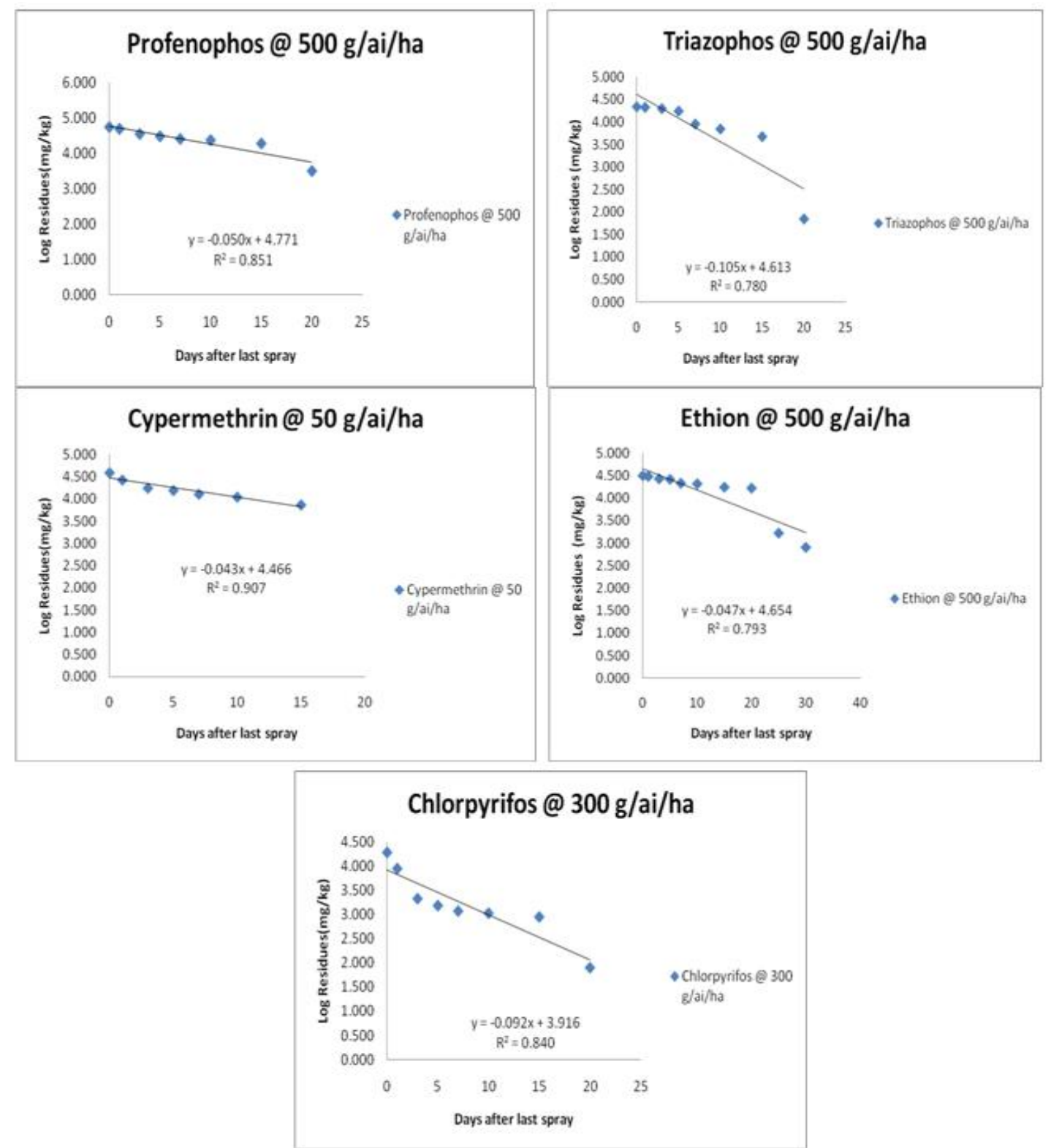

Figure 2: Semilogorithmic graph depicting dissipation kinetics of Chlorpyriphos, cypermethrin, ethion, profenophos and triazophos on/in Curry Leaf 

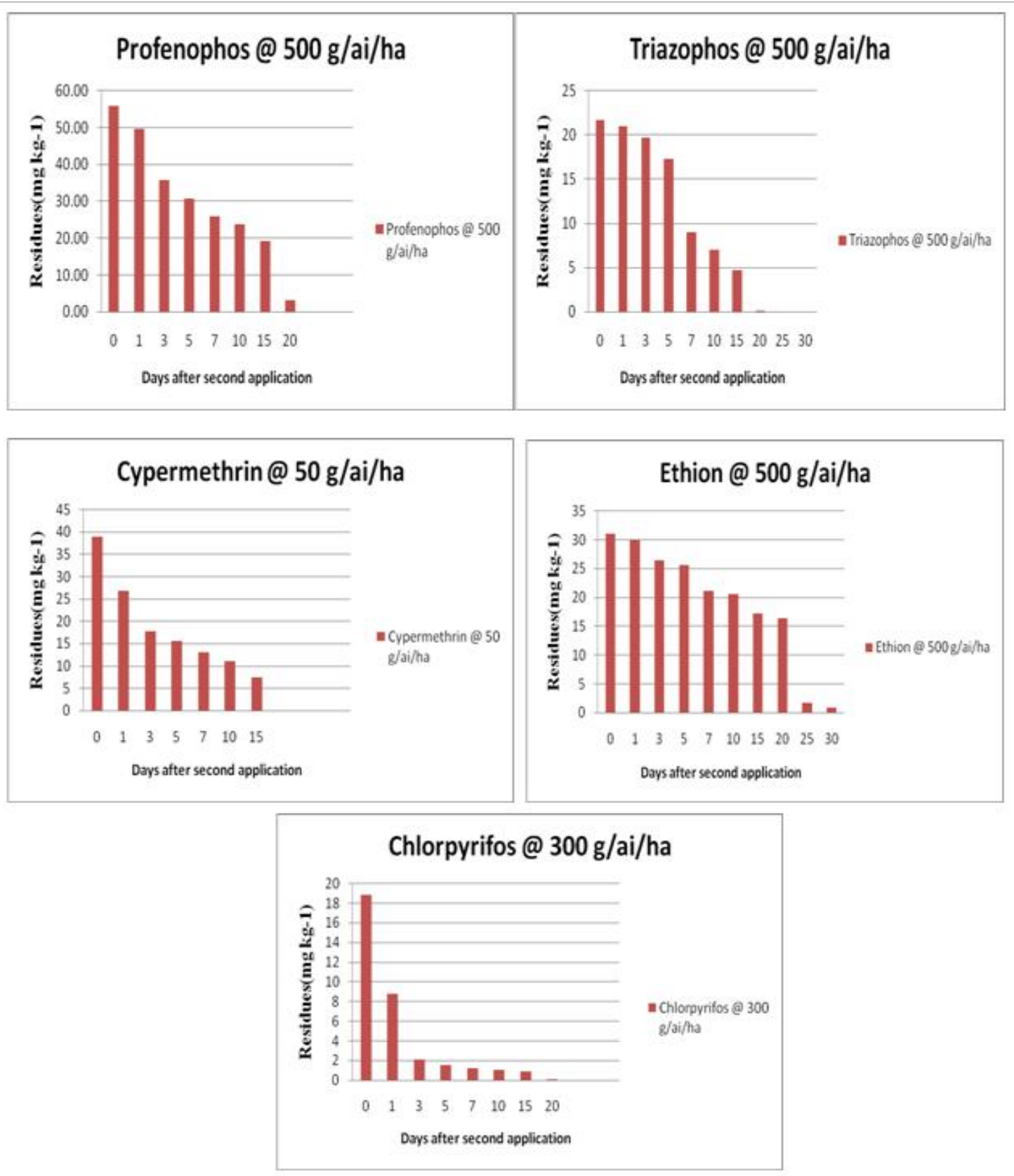

Figure 3: Dissipation dynamics of Chlorpyriphos, cypermethrin, ethion, profenophos and triazophos in curry leaf.

Certified Reference Materials (CRM) of different pesticides having purity ranging from 95.10 to 99.99 percent were stored in a freezer at low temperature, with light and moisture excluded. Solvents used in the study were all glass distilled before use. Sodium sulphate, sodium chloride and magnesium sulphate were activated in hot air oven at $450^{\circ} \mathrm{C}$ for $5 \mathrm{~h}$. A weighed amount of analytical grade material of each pesticide was dissolved in a minimum quantity of distilled acetone and diluted with methanol to obtain a stock solution of $1000 \mathrm{mg} \mathrm{kg}^{-1}$. The intermediate standards and working standards of $0.5,0.25,0.1$, $0.05,0.025$ and $0.01 \mathrm{mg} \mathrm{kg}^{-1}$ were prepared by suitably diluting the stock solution in methanol and used as standard check in analysis, linearity and recovery studies (Table-2) (Figure 3).

- The recovery of Profenophos is $106.66 \%$ from the curry leaf samples fortified at $0.05 \mathrm{mg} / \mathrm{kg}$, and $83.06 \%$ recovery at 0.25 $\mathrm{mg} / \mathrm{kg}$ fortified level while the samples fortified with $0.50 \mathrm{mg} /$ $\mathrm{kg}$ have shown the recovery of $98.06 \%$.
- Hence, the limit of quantitation (LOQ) is $0.05 \mathrm{mg} / \mathrm{kg}$ for Profenophos in curry leaf.

- The recovery of Triazophos is $85.33 \%$ from the curry leaf samples fortified at $0.05 \mathrm{mg} / \mathrm{kg}$, and $84.00 \%$ recovery at $0.25 \mathrm{mg} / \mathrm{kg}$ fortified level while the samples fortified with $0.50 \mathrm{mg} / \mathrm{kg}$ have shown the recovery of $97.60 \%$.

- Hence, the limit of quantitation (LOQ) is $0.05 \mathrm{mg} / \mathrm{kg}$ for Triazophos in curry leaf.

- The recovery of Chlorpyrifos is $94.66 \%$ from the curry leaf samples fortified at $0.05 \mathrm{mg} / \mathrm{kg}$, and $104.53 \%$ recovery at 0.25 $\mathrm{mg} / \mathrm{kg}$ fortified level while the samples fortified with $0.50 \mathrm{mg} / \mathrm{kg}$ have shown the recovery of $115.60 \%$.

- Hence, the limit of quantitation (LOQ) is $0.05 \mathrm{mg} / \mathrm{kg}$ for Chlorpyrifos in curry leaf.

- The recovery of Cypermethrin is $115.33 \%$ from the curry leaf samples fortified at $0.05 \mathrm{mg} / \mathrm{kg}$, and $97.60 \%$ recovery at 0.25 $\mathrm{mg} / \mathrm{kg}$ fortified level while the samples fortified with $0.50 \mathrm{mg} /$ $\mathrm{kg}$ have shown the recovery of $114.86 \%$. 
- Hence, the limit of quantitation (LOQ) is $0.05 \mathrm{mg} / \mathrm{kg}$ for Cyper- References methrin in curry leaf.

- The recovery of Ethion is $101.33 \%$ from the curry leaf samples fortified at $0.05 \mathrm{mg} / \mathrm{kg}$, and $82.00 \%$ recovery at $0.25 \mathrm{mg} / \mathrm{kg}$ fortified level while the samples fortified with $0.50 \mathrm{mg} / \mathrm{kg}$ have shown the recovery of $101.13 \%$.

- Hence, the limit of Quantitation (LOQ) is $0.05 \mathrm{mg} / \mathrm{kg}$ for Ethion in curry leaf.

\section{Results and discussion}

It is seen from the results that the residues of all five pesticides were existing in curryleaf upto 20 days except for those of cypermethrin which dissipated to BDL by 20 days. However the residues of ethion persisted upto 30 days and reached BDL by 35 days.( Table-2). Hence care is to be taken while recommending pesticides on curryleaf as no MRL are set and the crop has high export potential. Intensive cultivation technologies produce high infestation of crops by some pests and diseases, trigger off major losses of quality crops and initiate the use of more pesticides. The increase in frequency and magnitude of residues in the curry leaf samples could be attributed to indiscriminate and over use of pesticides by farmers despite efforts by various concerned agencies. It has been found that the farmers are neither following recommended waiting periods nor abide by good agricultural practices (GAP) ${ }^{[11-13]}$. Therefore, an effective way of educating the farmers via., training and electronic media is advised particularly in view of the export potential of the crop. It is, therefore, suggested that the curryleaf collected from the markets of Hyderabad, Telangana, India are to be consumed after proper washing and decontamination methods. Periodical monitoring studies of pesticide residues may be extended to different agro climatic regions to know actual status of contamination and to strengthen the confidence of consumer in quality of food as well as food quality control authorities for future policies.
1. Joseph, Salikutty., Peter, K. V. Curry leaf ( Murrayakoenigii ), perennial, nutritious, leafy vegetable. (2008) Economic Botany 39(1): S68-S73.

2. Khanum, Farhath., Anilakumar, K. R., Sudarshana Krishna, K. R., Viswanathan, K.R., Santhanam, K. Anticarcinogenic effects of curry leaves in dimethylhydrazine-treated rats. (2000) Plant Foods for Human Nutrition 55(4): S347-S355.

3. Wu, T. S., Chan, Y. Y., Liou, M. J., Lin, F. W., Shi, L. S., Chen, K. T. Platelet aggregation inhibitor from Murraya keonigii. (1998) Phyto therapy Research 12: 380-382

4. Chevallier,A. The encyclopedia of medicinal plants. (1996) Dorling Kindersley London, UK.

5. Tachibana, Y., Kikuzaki, H., Lajis, N. H., Nakatani, N. Comparison of antioxidative properties of carbazole alkaloids from Murraya koenigii leaves. (2003) J. Agric. Food Chem. 51(22): S6461-S6467.

6. Ningappa, M. B., Dinesha, R., Srinivas, L. Antioxidant and free radical scavenging activities of polyphenol-enriched curry leaf (Murraya koenigii L.) extracts. (2008) Food Chem. 106(2): S720-S728.

7. Chowdhury, B. K., Jha, S., Bhattacharyya, P., Mukherjee, J. Two new carbazole alkaloids from Murraya koenigii. (2001) Indian J Chem. 40(B): S490-S494.

8. Lee, J. C., Kim, J., Kim, H. R., Jang, Y. S. Antioxidant activity of ethanol extract of the stem Of Opuntia ficus-indica var. saboten. (2002) J Agric. Food Chem. 50(22): S6490-S6496.

9. Ramsewak, R. S., Nair, M. G., Strasburg, G. M., De Witt, D. L., Nitiss, J. L. Biologically active carbazole alkaloids from Murraya koenigii. (1999) J. Agric Food Chem. 47(2): S444-S447.

10. Khan, A. D., Bhatti, M. M., Khan, F. A., Naqvi, S. T., Karam, A. Adverse effects of Pesticides Residues on Biochemical Markers in Pakistani Tobacco Farmers. (2008) Int. J. Clin. Exp. Med. 1(3): S 274-S282. 11. Bhanti, M., Shukla, G., Taneja, A. Contamination levels of organochlorine pesticide and farmers' knowledge, perception, practices in rural India- A case study. (2004) Bull Environ. Contam. Toxicol. 73(5): S787-S793.

12. Fytianos,K., Vasilikiotis,G., Weil, L., Kavlendis, E., Laskaridis, N. Preliminary study of organochlorine compounds in milk products, human milk and vegetable. (1985) Bull Environ. Contam. Toxicol. 34: S504-S508.

13. Gupta, A., Singh, B., Parihar, N. S., Bhatnagar, A. Pesticide residues in the farm gate samples of bottle gourd, cauliflower, cabbage and fenugreek at Jaipur. (1998) Pesticide Res. J. 10(1): S86-S90.
Online ISSN: 2377-0619

Journal Title: International Journal Food and Nutritional Science Journal Short Name: Int J Food Nutr Sci
Ommega Online Publishers

E-mail: foodscience@ommegaonline.org Website: www.ommegaonline.org 